\title{
Use of Water Hyacinth and Fermented Fruit Waste as BSF (Black Soldier Fly) Media on The Quality of BSF Maggot Flour
}

\author{
Penggunaan Eceng Gondok dan Limbah Buah Terfermentasi sebagai Media Tumbuh BSF (Black Soldier Fly) \\ terhadap Kualitas Tepung Maggot BSF
}

\author{
F. Ardiansyah ${ }^{1}$, E. Susanto ${ }^{2}, \&$ Wahyuni $^{2 *}$ \\ ${ }^{1}$ Bachelor's Degree School Faculty of Animal Husbandry, Lamongan Islamic University \\ ${ }^{2}$ Faculty of Animal Husbandry, Lamongan Islamic University \\ J1. Veteran, No. 53A Lamongan 62213, Indonesia \\ *Corresponding author: yunipeternakan@gmail.com \\ (Received 22-10-2020; Revised 16-11-2020; Accepted 10-12-2020)
}

\begin{abstract}
This study aims to assess BSF maggot flour's quality using water hyacinth growing media and fermented fruit waste using EM-4 and molasses. Held a total of $70 \mathrm{~g}$ of baby maggot was in the temple for 15 days. Eldest the feed used using fermented water hyacinth and fermented fruit waste with four treatments consist of $P 0=0 \%$ fermented water hyacinth $+\mathbf{1 0 0} \%$ fermented fruit waste, $P 1=25 \%$ fermented water hyacinth $+\mathbf{7 5} \%$ fermented fruit waste, $P 2=50 \%$ fermented water hyacinth $+50 \%$ fermented fruit waste, and $\mathbf{7 5} \%$ fermented water hyacinth $+\mathbf{2 5 \%}$ fermented fruit waste. The design of the experiment uses a completely randomized design (CRD). The results showed that substitution of feeding $\mathbf{2 5 \%}$ fermented water hyacinth $+75 \%$ fermented fruit waste influenced the yield of BSF maggot flour $(P<0.05)$, and there was no effect on the pH quality of Maggot BSf flour $(\mathrm{P}>\mathbf{0 . 0 5})$. The best results' (substitution of feeding $\mathbf{2 5 \%}$ fermented water hyacinth $+\mathbf{7 5 \%}$ fermented fruit waste) has proximate content of dry matter $89 \%$, ash $11 \%$, crude protein $35.5 \%$, crude fat $12 \%$, calcium $7 \%$, nitrogen-free extract material $7 \%$, metabolist energy $2939.64 \mathrm{kcal} / 100 \mathrm{~g}$.
\end{abstract}

Keywords: water hyacinth, fruit waste, black soldier fly (BSF)

\begin{abstract}
ABSTRAK
Penelitian ini bertujuan untuk menilai kualitas tepung maggot BSF menggunakan media tanam eceng gondok dan limbah buah yang difermentasi menggunakan EM-4 dan tetes tebu. Sebanyak 70 gram bayi maggot sudah dipegang di Pura selama 15 hari. Pakan tertua yang digunakan menggunakan eceng gondok hasil fermentasi dan limbah buah fermentasi dengan empat perlakuan yaitu $\mathbf{P 0}=$ eceng gondok fermentasi $0 \%+$ limbah buah fermentasi $100 \%$, P1 = eceng gondok fermentasi $25 \%+$ limbah buah fermentasi $75 \%$, P2 = eceng gondok fermentasi $50 \%+50 \%$ limbah buah fermentasi, dan $75 \%$ eceng gondok fermentasi $+\mathbf{2 5} \%$ limbah buah fermentasi. Rancangan percobaan menggunakan Rancangan Acak Lengkap (RAL). Hasil penelitian menunjukkan substitusi pemberian pakan $75 \%$ limbah buah dan $25 \%$ eceng gondok terfermentasi memberikan pengaruh terhadap rendemen tepung maggot BSF $(\mathrm{P}<0.05)$ dan tidak ada pengaruh terhadap Kualitas $\mathrm{pH}$ tepung Maggot $\mathrm{BSf}(\mathrm{P}>0.05)$ maggot dapat tumbuh dan berkembang di media $\mathrm{pH}$ tinggi dan $\mathrm{pH}$ yang rendah yang akan berpengaruh pada ukuran tubuh maggot BSF. Kandungan proksimat dari hasil terbaik memiliki proksimat bahan kering sebesar 89\%, abu $11 \%$, Protein kasar $35.5 \%$, Lemak kasar 12\%, Calium 7\%, BETN 7\%, Energy metabolism $2939.64 \mathrm{kcal} / \mathrm{kg}$.
\end{abstract}

Kata kunci: eceng gondok, limbah buah, black soldier fly (BSF). 


\section{INTRODUCTION}

Water hyacinth is a wild plant that lives in water, usually found in swamps. The growth of water hyacinths is so fast that it reaches 3\% per day (Naji'ah and Nurul 2016). The growth rate of water hyacinth reaches $100 \%$ within two weeks (Ministry of Environment of the Republic of Indonesia 2014). The rapid growth of these plants causes flooding and disrupts irrigation channels. Therefore, the water hyacinth plant (Eichornia crassipes) needs control.

Water hyacinth is an aquatic plant that covers almost $85 \%$ of rivers and waters in Lamongan Regency (Naji'ah and Nurul 2016). In Lamongan District, water hyacinth were used as a handicraft and organic fertilizer to control water hyacinth growth. The low nutritional content of water hyacinths results in very low utilization of water hyacinth as animal feed. The provision of quality animal feed is one of the critical success factors in animal husbandry, namely 50-70\% (Katayane et al. 2014).

Able to use water hyacinth waste as animal feed is a growing medium for Black Soldier Fly maggot cultivation. Maggot is another name for the black soldier fly larva or Black Soldier Fly. So far, BSF breeders use growing media by utilizing organic waste. Such as market waste, household waste, agricultural waste, and livestock manure. The use of BSF larvae as water hyacinth processing is a promising opportunity because it can use the harvested BSF larva as a source of protein for animal feed.

Black Soldier Fly (BSF) (Hermetia illucens, Diptera: Stratiomyidae), is one of the various livestock that has begun to cultivate Indonesia widely. These flies originate from South America and then spread to subtropical and tropical regions (Čičková et al. 2015). Indonesia’s tropical climatic conditions are ideal for BSF cultivation.

BSF is also straightforward to develop and does not require special equipment. Not only that, but the BSF cycle is too swift. According to Tomberlin et al. (2002), BSF's life cycle from egg to adult fly lasts around 40-43 days, depending on environmental conditions and the feed media given.

BSF larvae are also rich in protein. The protein content in these larvae is relatively high, namely $44.26 \%$, with a fat content reaching $29.65 \%$. The values of amino acids, fatty acids, and minerals contained in the larvae are also not inferior to other protein sources, so BSF larvae are ideal raw materials that can make it as animal feed (Fahmi et al. 2007). A meal is essential to support the livestock industry's success and the most crucial essential requirement in this business activity, namely 50-70\% (Katayane et al. 2014).

The ability of BSF to eat organic waste makes it widely used as a decomposer agent. According to Diener et al. (2011), BSF can digest organic waste by reducing organic matter by $65.5 \%$ to $78.9 \%$ per day from the amount of food it gets. The ability of BSF to process organic materials is supported by the BSF digestive system, which has a natural microbiome that helps the decomposition process of organic matter. BSF larvae also have antibacterial properties (Escherichia coli O15: H7, Salmonella enterica serovar
Enteritidis) and antivirals (enterovirus and adenovirus) (Wardhana 2016). According to Yu et al. (2011), BSF also has various symbiotic bacteria, including Bacillus sp., Bacillus sp., known to be useful as a plant pathogen control agent.

The protein content in BSF larvae was relatively high, reaching $44.26 \%$ with a fat content reaching $29.65 \%$. So that BSF larvae are raw materials that can be as animal feed (Fahmi et al. 2007). The ability of BSF to process organic material is supported by cellulosic bacteria in the BSF digestive system to help convert organic waste such as fruit waste, vegetable waste, and livestock manure into fat and protein in its body biomass (Zheng et al. 2011).

So far, research has never been carried out on water hyacinth waste as a medium for growing BSF larvae. Opinion (Sari et al. 2017) Water hyacinth has 7.98\% lignin, $27.71 \%$ cellulose. Meanwhile, rice straw contains 35.49\% cellulose and 14.84\% lignin (Pan et al. 2017).

The way to convert water hyacinth into animal feed that is easily digested and has high nutritional content for livestock is using fermentation technology in water hyacinth, according to (Nainggolan et al. 2018). Similar research uses fermentation technology conducted by Pamukas and Khasani (2010), fermentation of animal feed, and agricultural waste applied to ruminants. Fermentation technology carried out using microbes contained in the effectiveness of microorganisms (EM-4). EM-4 in the composting process can speed up composting by 3-5 days (Yuwono 2005).

EM-4 is a liquid containing 80 genus of fermentable microbes and can ferment organic matter effectively. EM-4 consists of 5 main groups: bacteria lactobacillus sp, photosynthetic, saccharomyces $\mathrm{sp}$, actinomycetes $\mathrm{sp}$, and fermented fungi (Yuwono 2005).

The large number of water hyacinths that have not been utilized as animal feed, necessary to research the effect of water hyacinth waste as a growing medium for BSF (Black Soldier Fly) on the quality of BSF maggot flour. It will be an observation on chemical characters which include proximate content, $\mathrm{pH}$ and physical characteristics. Consists of the yield value and density of BSF maggot flour.

\section{MATERIALS AND METHODS}

Conducted this research was on March 4, 2020 - April 6, 2020. Implemented by UPT. Agri Science Technopark, Lamongan Islamic University, Lamongan Regency. The materials needed in this study are 10 grams of black soldier fly eggs, seven-day-old black soldier fly larvae, $2 \mathrm{~kg}$ of hatchery media (511 chicken feed), water hyacinth that fermented on 7 days, 7 days fermented fruit waste, EM-4, Molasses, and water. The tool used is a plastic bucket with a diameter of $30 \mathrm{~cm}$ to place the baby maggot to be treated, a green net to separate the maggot from the media, a mini digital scale for weighing maggot, a bucket for the sieve media, a $30 \mathrm{~cm}$ x $80 \mathrm{~cm}$ Styrofoam box for fermentation of fruit waste and water hyacinth, blender for smoothing fruit waste, and a $100 \mathrm{~mL}$ measuring tube for measuring EM-4 and molasses administration. 
There are steps before and during data recording. Measurement of body weight was carried out twice: before treatment and after treatment for seven days.

\section{Making Planting Media}

The water hyacinth is then ground first using a grass chopper to make it smaller by $3 \mathrm{~cm}$, then dried in the sun until the water content the reduced to $50 \%$. After drying the water hyacinth, weigh it and give it the treatment, add EM-4 and Molasses, after mixing it, then put it in a teraphim box and close it tightly and let it stand for ten days.

\section{Flour Making}

It was making BSF maggot flour done by killing/ turning off BSF maggot by soaking in $100{ }^{\circ} \mathrm{C}$ hot water for 5 minutes, then drying under the sun with a temperature of $50{ }^{\circ} \mathrm{C}$ for several days until dry, after drying the process then oven with a temperature of $50^{\circ} \mathrm{C}$ for 12 hours so the water content the wholly lost. After that, the dry BSF maggot is ground until it is smooth and shaped like flour.

\section{Chemical Characteristics}

Water Content Analysis, Oven Method (AOAC 2005), Ash Content Analysis (AOAC 2005), Protein Content Analysis, Kjeldahl Micro Method (AOAC 2005), the results of distillate titrated with $0.02 \mathrm{~N} \mathrm{HCL}$, and the endpoint of the titration marked by changing color yellow; Blank it also done the same way. Analysis of Fat Content, Soxhlet Method (AOAC 2005), Analysis of Fiber Content (Sudarmadji 2003). Dry matter analysis (Tilman 1999).

\section{Physical Characteristics}

Kamba density (Singh et al. 2005). The material is put into a measuring cup and compacted until its volume reaches $100 \mathrm{~mL}$. All materials from the measuring cup are removed and weighed. The density of material Kamba expressed in $\mathrm{g} / \mathrm{mL}$, yield (Hustiany 2005). The amount of gain is calculated based on the percentage by weight of BSF maggot flour divided by the BSF maggot weight used as BSF maggot flour, multiplied by one hundred percent. The yield determined by the formula:

\section{Yield $\%=$ Weight of flour $(\mathrm{g}) \times 100 \%$ BSF maggot weight}

\section{Data Analysis}

The collected data then tabulated using Microsoft Excel. Statistical analysis performed using ANOVA with the SPSS program. If there is a difference, the Duncan further test carried out. The treathments are consist of $\mathrm{P} 0=0 \%$ fermented water hyacinth $+100 \%$ fermented fruit waste, $\mathrm{P} 1=25 \%$ fermented water hyacinth $+75 \%$ fermented fruit waste, $\mathrm{P} 2=50 \%$ fermented water hyacinth $+50 \%$ fermented fruit waste, and 75\% fermented water hyacinth $+25 \%$ fermented fruit waste. The design of the experiment uses a completely randomized design (CRD).

\section{RESULTS AND DISCUSSION}

\section{The Effect of BSF Planting Media on the Yield of Maggot Flour}

From the observations of the yield of maggot flour using water hyacinth growing media and fruit can see waste in Table 1. Based on Table 1, it can see that the rendement of BSF maggot flour using fruit waste planting media and fermented water hyacinth using molasses and EM-4 has a significant effect $(\mathrm{P}<0.05)$. The highest rendement of maggot flour is in P1. The yield of maggot flour in P1 is $20.1 \%$. The amount of gain in $\mathrm{P} 1$ the thought to be from a ration of $75 \%$ fruit waste and $25 \%$ water hyacinth, which contains the right nutrients so that BSF larvae can easily convert the media. This optimal maggot the growth obtained because of the elements of life necessities for larvae to fulfilled. Syahrizal (2014). While the lowest yield of BSF maggot flour at P3 was $18.18 \%$, this thought to be from providing a ration of $25 \%$ fruit waste and $75 \%$ fermented water hyacinth containing nutrients, not by the needs of BSF maggot, so it is difficult to convert the media. The feed media quality will affect providing nutrition for larvae to breed (Katayane 2014).

Table 1. Data on Randeman's Maggot Flour

\begin{tabular}{ccccc}
\hline Treatment & Deuteronomy & $\begin{array}{c}\text { Gross } \\
\text { Weight }\end{array}$ & $\begin{array}{c}\text { Dry } \\
\text { Weight }\end{array}$ & Randeman \\
\hline PO & 1 & 128.78 & 23.89 & 18.55 \\
& 2 & 127.45 & 23.27 & 18.25 \\
Mean P0 & 3 & 128.64 & 23.82 & 18.52 \\
P1 & 1 & 128.32 & 23.66 & 18.43 \\
& 2 & 191.53 & 39.09 & 20.41 \\
Mean P1 & 3 & 190.54 & 38.11 & 20.00 \\
P2 & 1 & 140.03 & 37.26 & 19.61 \\
& 2 & 140,86 & 26.09 & 18.52 \\
& 3 & 141.30 & 27.17 & 19.23 \\
Average P2 & & 140.91 & 79.78 & 56.62 \\
P3 & 1 & 123.83 & 22.64 & 18.28 \\
& 2 & 123.62 & 22.48 & 18.18 \\
& 3 & 123.43 & 22.32 & 18.08 \\
Mean P3 & & 123.62 & 22.47 & 18.18 \\
\hline
\end{tabular}

Note: above, it can see that the immersion of BSF maggot flour using fruit waste planting media and fermented water hyacinth using molasses and EM-4 has a significant effect $(\mathrm{P}<0.05)$. At $\mathrm{P} 0$, the wet weight is average128.32 gram, 23.67 gram dry weight, which yields $18.43 \%$ immersion. P1 wet weight 190.07 grams, dry weight 38.15 grams, which results in a $20.1 \%$ yield. P2 with a basic weight of 140.91 grams, dry weight of 26.52 grams, which yields $18.87 \%$. P3 wet weight 123.62 grams, 22.47 grams dry weight, which results in an $18.18 \%$ yield.

According to Azir et al. (2017), the lowest maggot flour yield by giving $100 \%$ fish waste resulted in an alkaline weight of 494.08 and an immersion of 8.23 . While the highest product of BSF maggot flour on the use of $50 \%$ fish waste media coupled with $50 \%$ coconut dregs resulted in an alkaline weight of 1,149.88 grams with a yield of $19.16 \%$. Evidenced by differences in the outcome of research results with several researchers, fish waste media has a higher protein content than the type of feed that uses fermented water hyacinth and fruit waste. 


\section{pH Quality Maggot Flour}

The $\mathrm{pH}$ analysis is the degree of acidity used to express the acidity or alkalinity of a solution. The $\mathrm{pH}$ quality of maggot flour can see the results of research on BSF planting media's effect on the $\mathrm{pH}$ quality of maggot flour in Table 2.

Table 2. Results of the Average Value of Maggot Flour pH Test

\begin{tabular}{cccccc}
\hline Treatment & \multicolumn{3}{c}{ Deuteronomy } & Jumlah & Average \\
\cline { 2 - 4 } & 1 & 2 & 3 & & \\
\hline P0 & 5.34 & 5.29 & 5.27 & 15.90 & 5.30 \\
P1 & 5.26 & 5.27 & 5.25 & 15.78 & 5.26 \\
P2 & 5.27 & 5.26 & 5.29 & 15.82 & 5.27 \\
P3 & 5.26 & 5.29 & 5.31 & 15.86 & 5.28 \\
\hline
\end{tabular}

Note: above shows that water hyacinth and fermented fruit waste were not significantly different $(\mathrm{P}>0.05)$ in BSF maggot flour's $\mathrm{pH}$ quality. The $\mathrm{pH}$ of maggot flour in table 4.3 shows an average value that does not differ between P0, P1, P2, and P3, namely P0 5.3\%, P1 5.28\%, and 5.27 , and $\mathrm{P} 35.26 \%$. There is no significant difference in the $\mathrm{pH}$ content of the maggot flour. It assumed that the media used does not affect the flour's $\mathrm{pH}$, and the growth of maggot does not affect media that has a high $\mathrm{pH}$ or a low $\mathrm{pH}$.

Table 2 shows that water hyacinth and fermented fruit waste were not significantly different $(\mathrm{P}>0.05)$ in $\mathrm{BSF}$ maggot flour's $\mathrm{pH}$ quality. The $\mathrm{pH}$ of maggot flour in Table 4.3 shows an average value that does not differ between $\mathrm{P} 0, \mathrm{P} 1, \mathrm{P} 2$, and $\mathrm{P} 3$, namely $\mathrm{P} 0=5.3, \mathrm{P} 1=5.28, \mathrm{P} 2=5.27$, and $\mathrm{P} 3=5.26$. There is no significant difference in maggot flour's $\mathrm{pH}$ content. It assumed that the media used does not affect the flour's $\mathrm{pH}$, and the growth of maggot does not affect media that has a high $\mathrm{pH}$ or a low $\mathrm{pH}$. Larvae of BSF can grow and develop in high $\mathrm{pH}$ and low $\mathrm{pH}$ media, which will affect the body size of the BSF maggot (Maneguz et al. 2018).

In $\mathrm{pH}$ test on fish meal. According to Sahril (2015), the $\mathrm{pH}$ content in a fish meal is 5.41 and can reduce by using an increase in acetic acid concentration to lower the $\mathrm{pH}$ of fish meal to a $\mathrm{pH}$ of 3.46. The $\mathrm{pH}$ content in maggot flour is the same as the $\mathrm{pH}$ content in acidic fish meal.

\section{Maggot Flour Proximate Test}

Based on the results, BSF maggot flour's physical parameters from the yield characteristics and $\mathrm{pH}$, the best quality obtained at P1, namely $75 \%$ fruit waste and $25 \%$ fermented water hyacinth. The best results then tested proximate. Can see the proximate test content of maggot flour in P1 treatment, which is harvested once with a harvesting age of 14 days, can be seen in Table 3. Based on Table 3 the proximate test results of BSF maggot flour showed that P1 treatment with $75 \%$ fruit waste and $25 \%$ fermented water hyacinth rations produced dry matter of $89 \%$, ash $11 \%$, crude protein $35.5 \%$, crude fat $12 \%$, Calcium $7 \%$, nitrogen- free extract nutrient $7 \%$, Energy metabolism $2939.64 \mathrm{kcal} / \mathrm{kg}$.

According to the proximate results conducted by Azir et al. (2017), obtained the highest maggot protein content was from giving the media that have hight content of protein like fish waste $50 \%+50 \%$ bran, which produced a crude protein of $42.22 \%$. The protein content of the medium is 43\%. Rahmawati et al. (2010) also argued that the highest maggot nutrient content at the age of 15 days using oil palm cake media had dry matter content of $37.94 \%$, crude protein $44.01 \%$, crude fat $19.61 \%$, and ash $7.65 \%$. The protein content of the medium is $46.11 \%$. Subamia (2010) states that maggots have storage organs called trophocytes which function to store nutrient content found in the culture media that they eat.

The decrease in BSF maggot flour's nutritional content, which uses a planting medium of $25 \%$ water hyacinth and $75 \%$ fruit waste, is thought to be due to insufficient nutrition content. The protein content of water hyacinth only 11,5\% (Ahmed 2012) and the protein content of fruit waste is only $1-17 \%$ (Jalaludin 2016). It is lower than fish waste and oil palm cake. The nutritional content contained in BSF maggot flour also decreases. Not only the lack of nutrients, but the water content in the media is also too high so that the high water content will only inhibit the growth of maggots, which will make the nutrient content of BSF maggots low. Hakim (2017) stated that the media's high water content caused larvae's difficulty reducing feed. As stated by Tran et al. (2014) noted that the water content of the press during larval cultivation must be low because the larvae cannot grow on the media when the water content is high. It also significantly affects the nutritional content of the BSF maggot.

\section{Protein Content}

Based on Table 4, maggot flour's proximate test results show that the protein content in $\mathrm{P} 3$ contains a protein of $35.47 \%$. Research conducted by Sheppard and Newton (2000) and Sogbesan, Ajuonu, Musa, and Adewole (2006) shows that maggot's protein content is relatively high. Maggot in dry form contains $41-42 \%$ crude protein.

According to Rahmawati's opinion et al. (2010), the highest maggot protein was 15 days, which contained

Table 3. Nutritional Content of Maggot Black Soldier Fly (BSF) Flour

\begin{tabular}{|c|c|c|c|c|c|c|c|c|}
\hline \multirow[t]{2}{*}{ Treatment } & \multicolumn{8}{|c|}{ Test Result } \\
\hline & $\begin{array}{l}\text { dry matter } \\
(\%)\end{array}$ & Ash (\%) & $\begin{array}{l}\text { crude protein } \\
\qquad(\%)\end{array}$ & $\begin{array}{l}\text { crude fat } \\
\qquad(\%)\end{array}$ & $\begin{array}{l}\text { crude fiber } \\
(\%)\end{array}$ & $\begin{array}{l}\text { Calcium } \\
(\%)\end{array}$ & $\begin{array}{c}\text { nitrogen-free } \\
\text { extract material } \\
(\%)\end{array}$ & $\begin{array}{c}\text { metabolist energy } \\
(\mathrm{Kcal} / \mathrm{Kg})\end{array}$ \\
\hline P1 & 89 & 11 & 35.5 & 12 & 7 & 6.5 & 7 & 2939.64 \\
\hline
\end{tabular}


$44.01 \%$. According to the proximate results conducted by Diener et al. (2009), the protein content of maggot (Hermetia illucens) using oil palm cake media contains $28.2-42.5 \%$ protein. The supporting factors for the amount of protein in the BSF maggot are the composition of the ingredients added to the maggot growing media in the form of fish waste added with vegetable waste materials bran and coconut dregs.

From the proximate test results conducted by Miskiyah et al. (2006), pure coconut dregs' protein content was $11.35 \%$. Apart from the bran and coconut dregs, this research also used a mixing ingredient in vegetable waste. From the proximate test results conducted by Muktiani et al. (2007), the traditional market vegetable waste contains $12.64 \%$ crude protein. The amount of protein content in the P3 culture media is due to the mixing media in $75 \%$ fruit waste, which has a greater nutrient content than water hyacinth mixed media. It is because maggot can store the nutrient content contained in the culture media it eats. According to Subamia (2010), maggots have storage organs called trophocytes, which function to keep nutrient content found in the culture media they eat.

\section{Fat Level}

Fat is a source of energy, apart from being a source of energy for fat and a medium for storing dissolved vitamins. From the proximate test results, the BSF P3 maggot fat content results were $12 \%$ Cicilia (2018) said that the crude fat content in BSF maggot was 17.11, while in BSF maggot flour was $34.36 \%$. Raharjo (2016) argues that the BSF maggot fed tofu dregs are as much as $50 \%$, and chicken manure $50 \%$ crude fat is $6.76 \%$. The amount of fat content in BSF maggot flour renew by the media eaten by BSF maggot.

\section{Ash Content}

Ash content is a mixture of components inorganic or mineral found in a foodstuff Kantun et al. (2015). From the proximate test results, the ash content in BSF P3 maggot flour was $11 \%$. This result considers acceptable because the high level of ash in the material indicates its high mineral content (Utami et al. 2013).

\section{The Effect of BSF Planting Media on the Density of Maggot Flour}

Based on the best quality results in P1, namely $25 \%$ fermented water hyacinth and $75 \%$ fruit waste. The best results are then in the density test. For the best results, maggot flour is put into a measuring cup and compacted until the volume reaches $100 \mathrm{ml}$. All maggot flour is removed from the measuring cup and removed and weighed. The density of material Kamba expressed in $\mathrm{g} / \mathrm{mL}$.

The analysis of the density of BSF Maggot flour, which a put into a $100 \mathrm{~mL}$ measuring tube, resulted in a flour weight of $45.8 \mathrm{~g} / \mathrm{mL}$. This value is still within the standard range of insect flour density. According to Jian (2019), the thickness of insect flour is less than $60 \%$. The drying process only relies on sunlight and in the sun for three days. After undergoing the drying process, we will carry out the milling process after milling the maggot flour, and it will be in the sun again for 2-3 days so that it is perfectly dry. The drying process greatly affects the density results of Indrayani flour et al. (2013).

\section{CONCLUSION}

Based on the results of the study, can be concluded that the media of fermented water hyacinth and fruit waste on the quality of BSF maggot flour affects the yield of BSF maggot flour and does not affect the $\mathrm{pH}$ of BSF maggot flour. Obtained the best results were at medium 25\% fermented water hyacinth and $75 \%$ fruit waste with a yield of $20.1 \%$ with a proximate content of dry matter $89 . \%$, ash $11 \%$, crude protein $35.5 \%$, crude fat $12 \%$, calcium $7 \%$, nitrogenfree extract material 7\%, metabolist energy $2939.64 \mathrm{kcal} /$ $100 \mathrm{~g}$, with the resulting density is less than $60 \%$ which is equal to $45.8 \mathrm{~g} / \mathrm{mL}$.

\section{REFERENCES}

Fahmi, M. R., S. Hem, \& I. W. Subamia. 2007. Potential of maggot as a source of protein for fish feed. In: Technology Support to Improve Animal Food Products in the Context of Fulfilling Community Nutrition. Proceedings of the XXVII World Food Day National Seminar. Bogor (Indonesia): Puslitbangnak. p. 125130.

Frin. 2017. Composition of black soldier fly prepupae and systematic approaches for extraction and fractionation of proteins, lipids, and chitin.

Katayane, A. F., F. R. Wolayan, \& M. R. Imbar. 2014. Production and protein content of maggot (Hermetia illucens) using different growing media. J Zootek. 34: 27-36.

Ministry of Environment of the Republic of Indonesia. 2014. Lake saving movement (Germadan) Kerinci. Ministry of Environment.

Naji'ah, E. F. \& B. Nurul. 2016. Utilization of water hyacinth waste based on relation ship training in Kemlagi Lor Village, Turi District, Lamongan Regency. Journal of Management Science Research, Volume II No.2. June 2016.

Sari, E. S. Syamsiah, H. Sulistiyo, \& M. Hidayat. 2017. Water hyacinth biodelignification to increase degestibility in the Enzymatic Hydrolysis process. Reactors. 17(1): 53-58.

Supriyatna, A., \& Ukit. 2016. Screening and Isolation of Cellulolytic Bacteria from Gut of Black Soldier Flys Larva (Hermetiaillucens) Feeding with Rice Straw. Journal of Biology \& Biology Education. Bioscience. 8(3): 314-320.

Supriyatna, A., \& R. E. Putra. 2017. Estimation of Growth of Black Soldier Fly Larvae (Hermetia illucens) and Usage of Fermented Rice Straw Feed with P. chrysosporium Fungi. Biodiversity Journal. 2(2): 159166.

Tomberlin, J. K., D. C. Sheppard, \& J. A. Joyce. 2002. Selected life history traits of Black Soldier Flies Diptera. 
Tschirner, M., \& A. Simon. 2015. Influence of different growing substrates and processing on the nutrient composition of black soldier fly destined for animal feed. Journal on Insects as Food and Feed. 1 (4): 249259.
Zheng, L., Q. Li, J. Zhang, \& Z. Yu. 2011. Doeble the Biodiesel Yield: Rearing Black Soldier Fly Larvae, Hermetia illucens, on Solid Residual Fraction of Resteurant Waste After Grease Extraction for Biodiesel Production. Renewable energy. 1-5. 